\title{
EXAMINING THE RELATIONSHIP BETWEEN FIRM SIZE AND EXTERNAL ADVICE ON LEGAL MATTERS AND HUMAN RESOURCES BY FAMILY BUSINESSES
}

\section{Sonia BENITO-HERNÁNDEZ1 ${ }^{1}$, Cristina LÓPEZ-CÓZAR-NAVARRO², Tiziana PRIEDE-BERGAMINI ${ }^{3}$}

\author{
1, 2 Universidad Politécnica de Madrid, Av. Complutense s/n 28040, Madrid, Spain \\ ${ }^{3}$ Universidad Europea de Madrid, C/Tajo s/n 28670, Madrid, Spain \\ E-mails: ${ }^{1}$ sonia.benito@upm.es (corresponding author); \\ ${ }^{2}$ cristina.lopezcozar@upm.es; ${ }^{3}$ tiziana.priede@uem.es
}

Received 14 September 2012; accepted 04 February 2013

\begin{abstract}
In this paper the authors study the relationship between the use of external advice and the size of a Spanish family business, focusing especially on the advice on legal matters and human resources, due to the importance of these particular issues for family firms. To fulfill this objective, an in-depth review of the literature has been performed, as well as an empirical study. The results show that a family nature of business has a positive impact in the use of human resources management external advice. Nevertheless, for legal advice no relationship can be found. Finally, in line with the literature and the results of the analysis, no positive relationship has been found between family business size and the use of external advice, in comparison to the results for companies in general. The scarcity of published work about the issue and the results obtained, especially those related to the use of legal advice for family business managers, make this paper useful for researchers and businesses managers.
\end{abstract}

Keywords: family business, human resources advising, legal advising, size, external advice, family business management, family nature.

JEL Classification: M21, M29, C13.

\section{Introduction}

Family firms are the predominant form of business in many countries, and they contribute extensively to worldwide economic production, job and wealth creation (Astrachan et al. 2003). Nevertheless, family owned companies present a very high rate of failure due to the problems that arise when the family is owner and, at the same time, manager of the business. In fact, there is an extensive amount of analysis in the literature focusing on problems caused by generational changeovers, such as a lack of professionalism and very poorly defined organizational structures (e.g., Gallo, García-Pont 1996; Graves, Thomas 2004). In this sense, to know and understand the major issues regarding family 
firms is of great interest, not only to owners and managers, but also to those who work advising these companies (Sonfield, Lussier 2008).

Family firms present, in broad terms, a smaller size and more limitations than non-family firms (Daily, Dollinger 1992). In most cases, they cannot afford to recruit professional managers. A very interesting alternative arises with the possibility of hiring the services of external advisors, in order to help managers when facing important decisions. In fact, over the last thirty years, external advice services have increased substantially in most developed economies and more recently in developing countries.

The use of external advisors in family firms is seldom dealt within the literature, despite its helpfulness for family firm managers. Based on this, we believe that there is a gap in this field and a great deal of interesting research remains to be conducted. This is the aim of this paper, which analyzes the use of external advisors in family firms. It is important to highlight that the role of external advisors is different when dealing with family businesses because in this type of company the professional advisor needs to take into consideration the very powerful emotional and relational issues that will have an impact on the more traditional expert advice. Usually, family business consulting is more about families than it is about business, and issues are always much more complex than they seem (Tucker 2011).

The fact that the family business is usually smaller in size can be a factor directly related to the use of advice services. The literature includes studies that positively relate size with the use of external advice (Sonfield, Lussier 2008) with questions arising such as: what kinds of companies use external advice? Does the family nature of the firm have an influence in the decision of whether or not to use external advice? In order to answer these questions the present paper proposes three main objectives: (1) to confirm that there is a positive relationship between size and the use of external advice, especially in issues regarding legal matters and human resources, (2) to analyze if family businesses really use significantly external advice in issues regarding legal matters and human resources in order to solve their limitations and problems in relation to their family nature, and (3) to find out if the positive relationship between size and use of external advice remains significant in the case of family businesses.

In general terms, the objective of this paper is to analyze empirically if family nature has an influence on the use of external advice in the Spanish family owned business. Special attention is focused on advice on legal matters and human resources (HR) because they represent two major issues in family businesses. Such issues include: planning succession, developing a family protocol, inheritance matters, a lack of professionalization of management teams, comprised of non-qualified family members (nepotism), and other issues regarding legal matters and human resources management. To reach the objectives stated, bibliographic references on the use of business advice by family owned businesses have been reviewed. An empirical study is also presented based on the data obtained in the Business Strategy Questionnaire (carried out by the SEPI Foundation and the Ministry of Science and Technology) of 2,013 industrial organizations (775 family owned and 1,238 non-family owned) within the Spanish industrial sector. The 
paper concludes with some final reflections based on the results obtained from the empirical comparison.

\section{Literature review and formulation of the hypotheses}

\subsection{External advice and firm size}

It is apparent that the literature traditionally studies the relationship between firm size (usually measured by the number of employees, the annual turnover, or the annual balance sheet) and factors such as credit worthiness of a business (Parker 1978; Romano et al. 2001), level of exportations (Arteaga, Medina 2006; Lucio et al. 2007; Claver et al. 2008), age of a company (Yasuda 2005; Park et al. 2010) and number of products on the market (Insik 2003; Hutchinson et al. 2010), among other factors. Poor management abilities and lack of expertise or knowledge have been cited as important reasons for failure (Chaganti, Chaganti 1983; Gaskill et al. 1993; Longenecker 2006; Dyer, Ross 2008). When managers cannot find the solution within the business, it is a good opportunity to shift the problem to a professional advisor (Robson, Bennett 2000). In fact, it is considered a major factor related to firm survival (Said 1977; Reynolds 1987; Kent 1994). In this manner, the literature has found a positive relationship between size and external advisors (Bennett, Robson 1999a; Boter, Lundstrom 2001; Leighton, Schaper 2003; Bennett, Robson 2005; Dyer, Ross 2008).

On the other hand, the main areas where business managers may hire advisors are: tax services, HR, marketing, financial management, accounting, information technologies, strategic management, and legal issues. Nevertheless, some authors logically point out that there are major differences when selecting the type of advice depending on the different types of firms, according to size, sector, age, and business life cycle (Smallbone et al. 1993; Bennett, Robson 1999a, 2003; Klyver 2008; Webber et al. 2010) and there is empirical evidence on the effect of each kind of advice on the rate of growth and results of the company (Robson, Bennett 2000), finding that not all of them have a significant positive effect. Along this same line, Kent (1994) found a positive relationship between the use of advice services and financial performance in small businesses. Others, such as Trau (1996) and Johnson et al. (2004), also found positive effects between advice results and growth, especially in small firms.

Nevertheless, knowledge about the characteristics of the companies that use external advice is relatively scarce; the literature reviewed confirms that the relationship between business characteristics and the use of external advice is very complex (Smallbone et al. 1993; Bennett, Robson 1999a, 2003; Johnson et al. 2004, 2007; Xiao, Fu 2009), with differences existing according to the type of advice. In fact, as was earlier pointed out there are empirical studies which indicate that not all have a positive relationship with the size and growth of the company (Robson, Bennett 2000). For this reason, to analyze if, effectively, there is a positive relationship between firm size and the use of external advice, especially in issues regarding legal matters and HR, a first basic hypothesis is formulated: 
$\mathbf{H}_{1}$ : The larger the company the greater the use of external advice on legal and human resources issues.

Although already analyzed in the literature, the paper aims to confirm this relationship for both specific types of advice in order to increase the robustness of the model presented and as a basis for the rest of the hypothesis.

\subsection{External advice and the family firm}

Regarding family business advice and despite the fact that the literature is not very extensive in this area, attempts have been made to analyze the use of external advice and its impact on businesses. Dyer (1988) and Aronoff (1998) found that as companies evolve and grow in size, a more professional management style develop with external advice accompanying the evolution. Sonfield and Lussier (2008) studied the relationship of firm size to a variety of management activities and characteristics. Based on the analysis of data gathered from 159 American family businesses, they found significant differences in size with relation to the use of external advisors; specifically, that larger family firms were more likely than smaller ones to use outside advisors, consultants and professional services. However, these same authors could not empirically confirm this hypothesis in a subsequently presented paper (Lussier et al. 2009).

As stated earlier, different types of advice may exist (financial, legal, fiscal, HR, etc.), Robson and Benett (2000) found differences between the type of advice, growth and size, not always finding a positive relationship between these variables. Along this same line, this paper focuses on the specific analysis of legal and HR advice in the family firms, because they are the two main worries that affect this type of company. Dealing with legal conflicts between family and business, and selecting and recruiting human resources, can both be major reasons for company failure (Gallo, García-Pont 1996; Graves, Thomas 2004). In this sense, it is expected that family firms will tend to use external advice, specifically in legal and human resources management (HRM).

\subsubsection{Human resources advice in family businesses}

According to resource-based theorists (e.g., Barney 1991; Peteraf 1993) HR are considered as one of the main intangible resources in most companies. Specifically in family businesses, the human team can achieve a very high degree of commitment and dedication, greater than in any other company. The special relationship between family, ownership and control, makes HR practices different in family business than in their non-family counterparts (Reid, Adams 2001; Gulbrandsen 2005; De Kok et al. 2006). Thus, the nature of family firms makes it sometimes difficult to integrate non-family employees into the firm. The members of the family are more flexible and highly motivated by the family ties and their unity and commitment to the project (Habbershon, Williams 2000; Gallo et al. 2001; Karlsson 2001; Poza 2004; Gallo et al. 2009; Priede, López-Cózar 2009; Ward 2011). In this sense, there is a greater human capital than there is in any other business and outsiders may not engage to the same degree with the project. Therefore, external advisors have a great responsibility in the process of recruiting and hiring new employees aligned with the ideas and values of the owner family 
in order to ensure success. In fact, Cabrera-Suárez et al. (2001) found that if external employees in family businesses feel they are part of the team, they will display a more enthusiastic attitude than if they were employees of non-family businesses.

An effective HRM for family firms requires policies and procedures in order to control, select and recruit personnel; training and professional development; as well as incentive systems and equality in relations with non-family employees. Most relevant articles in the literature review are Lansberg (1983) and Astrachan and Kolenko (1994). Although in recent years interesting papers had been published, such as Kotey and Folker (2007) on training; Danes et al. (2009) on the importance of family capital on family firms, and Dawson (2012) on the construction of human capital in family businesses, in general, research on HRM in family firms is very limited (Benavides et al. 2011). In turn, Gulbrandsen (2005) concludes that family firms need external advice on HR. Surprisingly, the literature shows that family businesses tend not to use professionalized procedures for HRM practices and hesitate to use external advice on this matter (Reid, Adams 2001). In the same line, De Kok et al. (2006) state that family owned business tend to use less professional HRM practices than non-family firms. For this reason, this paper intends to empirically demonstrate the relation between the use of external advice in HRM and the family character through the formulation of Hypothesis 2 :

$\mathbf{H}_{2}$ : The family nature of the business has a significant effect on the use of external advice for selection and recruitment.

Focusing now on the relationship between HR advice and firm size, large companies show, in broad terms, professionalized procedures for HRM, while smaller ones use more informal and flexible systems (Barron et al. 1987; Saari et al. 1988; Hornsby, Kuratko 1990; Deshpande, Golhar 1994; Barber et al. 1999). Recruitment methods, such as the use of employment agencies, are regarded as formal methods, while referrals are regarded as informal ones (Taylor 1994). In this sense, the larger the company is the greater the use of external advice for recruiting and hiring personnel (Alewell et al. 2011).

Family firms are reluctant to use external advice in these matters because they tend to be smaller, less complex organizations and with more limited resources (De Kok et al. 2006). However, when they start to grow, it is not so clear whether they modify this behavior, as non-family businesses tend to do. As mentioned before, Lussier et al. (2009) could not demonstrate empirically that bigger companies with formal structures use more advice in general. For this reason, we intend to go into greater detail in this matter, accepting or rejecting this hypothesis:

$\mathbf{H}_{3}$ : The larger family businesses are the ones that most use external advice for the recruitment and selection of human resources.

\subsubsection{Legal advice in family businesses}

The importance of the role of professional legal advice has been cited in the literature (Bagley 2008; Giles et al. 2009). This type of advice is based on the solution of legal problems associated with succession and other conflicts regarding family relationships 
(divorces, deaths, etc.). These are issues of major importance and concern, affecting the future of these companies (Chua et al. 2003) and indeed, one of the main causes of their mortality (Birley 1986; Lansberg, 1988; Handler 1994; Le Breton-Miller et al. 2004). At the moment of succession, the expertise of an external professional is very often required because important conflicts may arise if it is not dealt correctly and well planned for (Dyer 1986; Lansberg 1999; Sharma et al. 2000; Sharma et al. 2003; Le Breton-Miller et al. 2004).

Nevertheless, although many family businesses are making such succession plans (Sharma et al. 2000), in most cases planning is done in a very informal way with very little use of or reliance on advisors or outside consultants (Morris et al. 1996; Astrachan et al. 2003; Matser, Lievens 2011). It is assumed beforehand that the successor is going to be a member of the founder's family (usually a son), who will continue with the management of the business (Handler 1989; Lansberg 1999). The succession plan should be included in the family protocol and the advisor should also support the preparation of the protocol according to the particular interests of each family, their values, and their culture, adapting to and understanding the family's real needs (Tucker 2011).

But succession is not the only issue that generates conflict within a family business. Divorce is also a frequent cause of significant problems (Rollock 1998). Before problems arise, an external advisor should intervene in order to suggest the best marriage property regime for each situation. The responsibility of the advisor in these issues is to prevent the conflict from occurring, and of course, avoid the failure of the business. Legal advice may also contribute to preserving and transferring the unique, valuable and non-imitative intangible resource called familiness, which is one of the most important strengths in a family firm, and probably, in most cases, the key to its success. Such commitment, shared values, culture, trust and reputation belong to the family and the business and are embedded in each particular context, so that transmission is very difficult and only possible through a slow process (Cabrera et al. 2001).

For this reason, the paper will try to empirically demonstrate the relationship between the use of legal advice and family nature, thus, hypothesis four is stated as follows:

$\mathbf{H}_{4}$ : The family nature of the business has a significant effect on the use of external legal advice.

With regard to the relationship between legal advice and size, very few studies have been done on the matter. López and Rosell (2007) for a sample of Spanish manufacturing companies, stated that the sign (positive or negative) of the relationship between size and outsourcing activities, including legal advice, cannot be prior predicted, although a relevant significance is found. In relation to family firms, it is also a matter not widely analyzed and, as well, shows no general agreement regarding the results. On one hand, Beckhard and Dyer (1983) found that conflict between family members increases with the number of generations implicated in the firm, in this sense, we understand that the higher the number of generations involved, the greater the size of the company, and thus the greater the need of external legal advice. On the other hand, other research shows that the larger the company, lower the probability of family members being involved, and thus less 
possibility of conflicts. For example, Sonfield and Lussier (2008) conclude that smaller family firms have more conflicts than larger ones. Therefore, since there is a lack of agreement in the literature concerning the relation between size and the use of legal advice in family firms, we suggest Hypothesis 5 to contrast the results with the proposed sample.

$\mathbf{H}_{5}$ : The larger family businesses are the ones that most use external legal advice.

\section{Data analysis and methodology}

\subsection{Sample and data collection}

This study has gathered data from the Survey on Business Strategies (ESEE, Encuesta sobre Estrategias Empresariales). One of the salient features of the ESEE is representative sampling. The initial selection of companies was made by combining the criteria of completeness and random sampling. The first group included firms with more than 200 employees, which was a requirement to participate. The second group was formed by companies that employed between 1 and 200 workers, which were selected by stratified sampling with proportional restrictions, and random start. Table 1 shows the technical data from the study.

\subsection{Variables and measures}

\subsubsection{Dependent variables}

To study whether or not advice regarding selection and recruitment is used by the companies, specially, in family firms that form part of the sample, the AD_HR variable was used. In addition, the AD_LEG variable has also been used in the case of legal advice. Both variables are dichotomous, taking the value 0 if the company does not use such advice and a value of 1 if it does. The use of advice was also measured dichotomously in works such as Bennett and Robson (2004), Merino and Rodriguez Rodriguez (2007), $\mathrm{Xiao}$ and $\mathrm{Fu}$ (2009).

Table 1. Technical data from the study

\begin{tabular}{ll}
\hline Population & \\
\hline Unit & Spanish manufacturing sector \\
$\begin{array}{l}\text { Questionnaire design } \\
\text { Population types }\end{array}$ & SEPI Foundation \\
Meach & Nore than 100,000 elements \\
Time period & Dational from 2007-2008 \\
\hline Sampling & \\
\hline Type of sampling & Random stratified census according to activity sector and firm size \\
Sample size & 2,013 Spanish manufacturing firms \\
Sampling error & $0.02(\mathrm{p}=\mathrm{q}=0.50)$ \\
Level of confidence & $95 \%(\mathrm{~K}=2$ sigma) \\
Data treatment & Statistical Solutions for Products and Services (SPSS) \\
\hline
\end{tabular}

Source: author-compiled data. 


\subsubsection{Independent variables}

The first independent variable to be studied is firm size. Many authors have used this variable to study corporate behavior (Bonaccorsi 1992; Calof 1994) and, more specifically, there are also many studies that have related the size of the company in general to the advice (O 'Farrell et al. 1993; Bennett, Robson 1999a; Xiao, Fu 2009). However, few studies have examined this relationship in the case of the family firm (Dyer 1988; Aronoff 1998; Sonfield, Lussier 2008; Lussier et al. 2009).

To give greater robustness to the results obtained in the econometric analysis, the study was performed with two different dependent variables, both representing the same concept: the size of the company. The first variable is measured by the variable logarithm ofnet sales (SIZ) (Larimo 1997; Claver, Quer 2007; Claver et al. 2008) and the second by the logarithm of the number of employees (SIZ*) (Bennett, Robson 1999a, 1999b).

Moreover, the Family Character (FAM) variable has been included. This variable explains whether the family nature of the companies influences the use of external advice on HR and legal issues. Different studies claim that family firms tend to use less of these types of consultancy. However, this may be because many of them use samples of SMEs (Reid, Adams 2001; De Kok et al. 2006; Matser, Lievens 2011). In the present study a sample that includes companies of all sizes has been used, in order to find out whether the behavior of this variable remains the same as in the studies cited. This variable (FAM) has been used and measured dichotomously in numerous studies on different aspects of the management of the family business (eg, Fernández, Nieto 2005; Jorissen et al. 2005).

To complete the study and establish a specific relationship between family businesses that do use this type of advice and their size, this paper has included two other variables in the form of interactions (Table 2). There is no evidence in the literature of the use of these variables created by way interactions in the specific issue of external advice. However, there are precedents of using interactions on other issues relating to the management of SMEs and family businesses (Lin, Germain 2003; Stern, Henderson 2004).

\subsubsection{Control variables}

Four control variables have been included that may help explain the use of advice. Studies like those of Bennett and Robson (1999b), Xiao and Fu (2009) include the variable age of the firm (AGE) to evaluate its relationship with the advice. The age of a business is a factor that may affect positively its size (Robson, Bennett 2009; Yasuda 2005; Park et al. 2010) therefore a positive relationship is expected between it and the use of advice. However, the work of Xiao and Fu (2009) failed to demonstrate its significance, and the study by Bennett and Robson (1999b) only managed to demonstrate its significance $(0.05<\mathrm{p}<0.1)$ with one types of advice out of six. Bennett and Robson (2004), Xiao and Fu (2009) found a positive relationship between the dependent variable and export activity. As in these studies, the export activity has been measured as a dichotomous variable. It takes a value of 1 when the business exports and a value of 0 when it does not (EXP). Another control variable used is the debt level of the 
firm (DEB). Studies such as Prodan and Slavec (2004) claim that the use of advice is significantly and positively related to small firm debt financing. In this paper, the debt level is measured by the ratio of outside debt to total liabilities. This ratio explains how a company can finance its activity with its own resources and what degree of dependency lies with external agents:

$$
\text { DEB }=(\text { Debt } / \text { liabilities }) * 100 .
$$

The last control variable analyzed is diversification (DIV). As reviewed in the literature, diversification along with expansion is a form of business growth (Barrett, Mayson 2007; Insik 2003, Hutchinson et al. 2010). While it is true that many family businesses are diversified, its management is not easy and requires a good team and a board to oversee it (Nueno 2011). This is one reason why some studies argue that firms that grow and diversify their activities are more likely to use formal mechanisms for managing staff (Barrett, Mayson 2007). In addition, due to their growing complexity they tend to need external support in other areas such as legal issues. Studies like Watson (2007) find a positive relationship between legal advice and companies that follow business growth strategies. In this paper, DIV has been included as a continuous variable that takes its value depending on the number of different products offered by the companies. Table 2 describes the variables that make up the study.

\subsection{Methodology}

The interaction between the family character and the size with the use of external advice is explored using a large scale survey of 2.013 firms in Spain only covering the manufacturing sector. Using this sample, we assess the use of two types of external advice, namely, HR and legal. The assessment is developed, first, by using descriptive statistics to compare the features of the different types of firms in the sample: family and non-family businesses. This descriptive analysis is completed with a test of equality of means. This enables us to check whether the differences between the means of the different variables used to analyze the two types of firms in the sample, are really significant. Thus, for continuous variables ANOVA is to be used, while for ordinal variables the "U" Mann-Whitney test and for nominal variables we use the Chi-Square test. Regarding family firms, Lee (2006) has used this same type of test in order to compare the results among companies of this nature.

Finally, a third element of evaluation has been added, the use of statistical regression estimation based on the General Linear Model (GLM), so as to evaluate the existence of dependence relations between the family nature and size, both of family and nonfamily businesses, with the use of external experts. This kind of statistical analysis has been applied because, in the cases in which the dependent variable is dichotomous, the literature agrees that the estimation of a model through an OLS regression analysis could produce bias problems, even heteroscedasticity. Thus, the use of a symmetric distribution (standard of logistic) and a Maximum-Likelihood estimator, as in the general linear model, it is necessary. This model was formulated by Nelder and Wedderburn 
S. Benito-Hernández et al. Examining the relationship between firm size and external ...

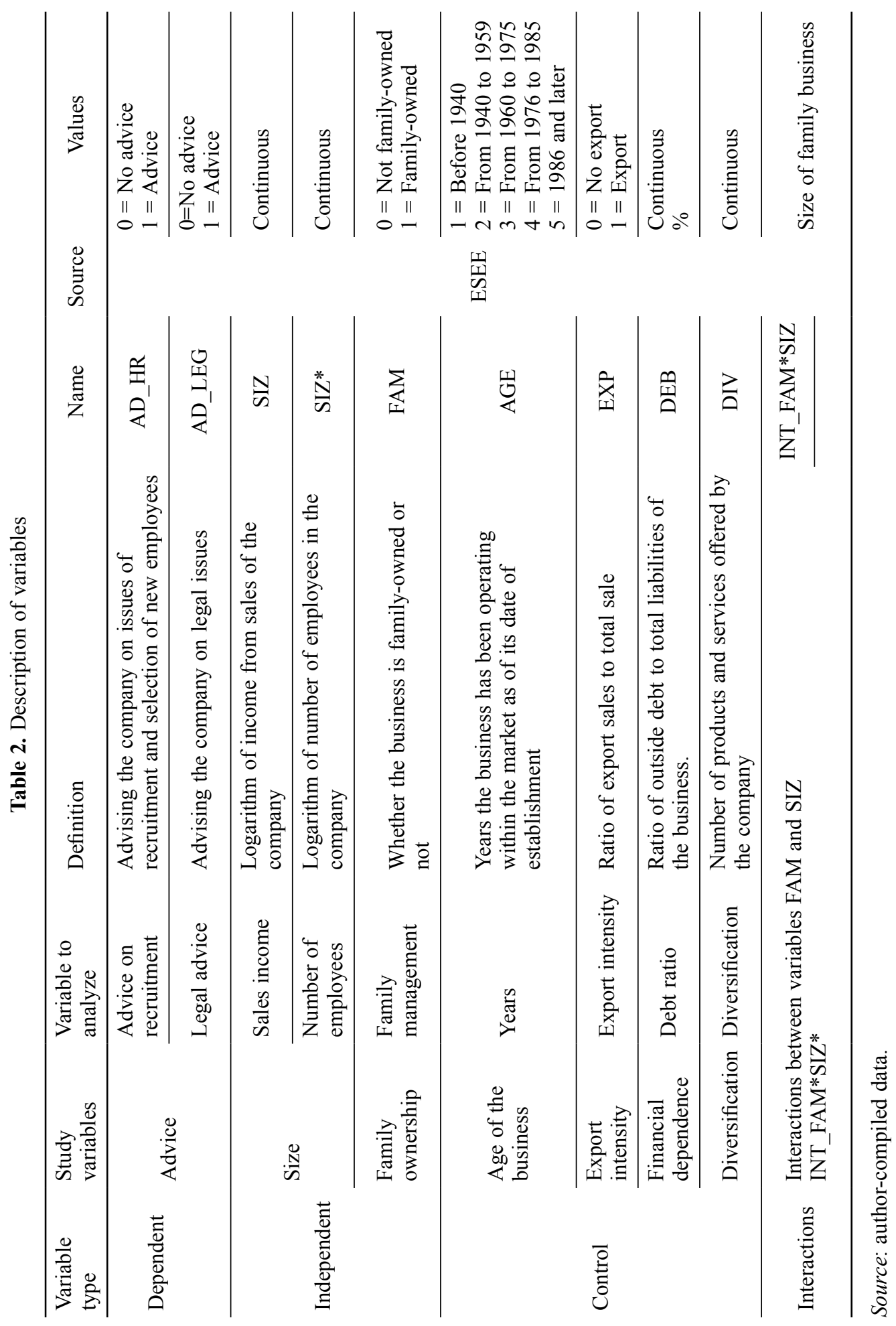


(1972) and developed by McCullagh and Nelder (1989) as a way of unifying various statistical models, including linear regression, logistic regression and Poisson regression, under one theoretical framework. The model has been widely applied in academic research because the parameter estimation, as well as its contrast restrictions, is well known (Greene 2000).

It should be noted that although no published works have been found on external advice and family businesses which specifically use the General Linear Model, Lansberg and Astrachan (1994) used this model to analyze issues regarding the management of the family business, in particular, family relationships and their influence on the succession process. In the same line, Torres-Fuchslocher and Fuente (2011) also applied GLM to analyze determinants of innovation for Chilean companies.

Several published works which have studied the use of external advice with cross section data and nominal or ordinal variables, have used models that have the same nature as the General Linear Model presented here. This is because this method can work with non-continuous dependent variables, and the estimation is performed by Maximum Likelihood and is a flexible generalization of OLS regression. Thus, the work of Xiao and $\mathrm{Fu}$ (2009), which studies the use of external advice by SMEs in China, defines a dichotomous dependent variable and uses the Binary Logistic Model. García Quevedo and Mas (2007) use the logit model to study the intensive knowledge counseling, relating it to firm size, using cross-sectional data. Likewise, Bennett and Robson (2004) use a logit model to study how the characteristics of the management team influence their propensity to seek advice. In this paper we use two econometric models, the Binary Logistic Model and the General Linear Model, yielding results of similar interpretation in both. Finally, we chose to present the results of the latter.

Research like Merino and Rodriguez Rodriguez (2007) use the ESEE survey and crosssectional data, using a probit model as its dependent variable taking three values, and the purpose of their work is to study the origin of advisory services used by companies. Robson and Bennett (2000) also use cross-sectional data and, as its dependent variable is continuous, use a Linear Regression Model. Finally, two types of analysis have been developed, the first, Models 1 and 2 contains the $\mathrm{H}_{1}, \mathrm{H}_{2}$ and $\mathrm{H}_{4}$. The second analysis, Models 3 and 4, includes the hypotheses $\mathrm{H}_{3}$ and $\mathrm{H}_{5}$.

\section{Results and discussions}

Descriptive results and correlations between variables are discussed first, so as to then present the results of the four proposed econometric models, contrasting the five hypotheses. Table 3 shows the descriptive statistics of the variables in both analyses. It also makes a supplementary examination dividing the sample between family and nonfamily firms.

To complete this descriptive analysis, a test for equality of means between family and non-family businesses was run using dependent and independent variables (Table 4). For this, the "t" or "ANOVA" factors test for continuous variables was used; DEB, DIV, 
Table 3. Descriptive statistics

\begin{tabular}{|c|c|c|c|c|c|c|}
\hline \multicolumn{3}{|l|}{$\begin{array}{l}\text { All companies } \\
\mathrm{n}=2.013\end{array}$} & \multicolumn{2}{|c|}{$\begin{array}{l}\text { Family companies } \\
\mathrm{n}=775\end{array}$} & \multicolumn{2}{|c|}{$\begin{array}{c}\text { Non family companies } \\
\mathrm{n}=1.234^{1}\end{array}$} \\
\hline Model variables & $\begin{array}{c}\text { Mean } \\
\text { (Max.-Min.) }\end{array}$ & $\begin{array}{l}\text { Standard } \\
\text { deviation }\end{array}$ & $\begin{array}{c}\text { Mean } \\
\text { (Max.-Min.) }\end{array}$ & $\begin{array}{l}\text { Standard } \\
\text { deviation }\end{array}$ & $\begin{array}{c}\text { Mean } \\
\text { (Max.-Min.) }\end{array}$ & $\begin{array}{l}\text { Standard } \\
\text { deviation }\end{array}$ \\
\hline AD_HR & $\begin{array}{c}0.90 \\
(0-1)\end{array}$ & 0.295 & $\begin{array}{c}\mathbf{0 . 9 1} \\
(0-1)\end{array}$ & 0.285 & $\begin{array}{c}0.89 \\
(0-1)\end{array}$ & 0.302 \\
\hline AD_LEG & $\begin{array}{c}0.88 \\
(0-1)\end{array}$ & 0.314 & $\begin{array}{c}\mathbf{0 . 8 7} \\
(0-1)\end{array}$ & 0.328 & $\begin{array}{c}0.89 \\
(0-1)\end{array}$ & 0.304 \\
\hline $\mathrm{SIZ}$ & $\begin{array}{c}6.96 \\
(4.78-9.88)\end{array}$ & 0.86 & $\begin{array}{c}\mathbf{6 . 8 5} \\
(5.11-9.83)\end{array}$ & 0.780 & $\begin{array}{c}7.02 \\
(4.78-9.88)\end{array}$ & 0.913 \\
\hline SIZ* & $\begin{array}{c}1.82 \\
(0-4.16)\end{array}$ & 0.635 & $\begin{array}{c}1.74 \\
(0.48-3.86)\end{array}$ & 0.571 & $\begin{array}{c}1.88 \\
(0.1-4.16)\end{array}$ & 0.667 \\
\hline FAM & $\begin{array}{l}0.38 \\
(0-1)\end{array}$ & 0.487 & - & - & - & - \\
\hline DEB & $\begin{array}{c}57.77 \\
(2.1-99.9)\end{array}$ & 28.80 & $\begin{array}{c}56.27 \\
(2.10-99.50)\end{array}$ & 23.031 & $\begin{array}{c}58.71 \\
(4.40-99.90)\end{array}$ & 22.624 \\
\hline EXP & $\begin{array}{c}0.62 \\
(0-1) \\
\end{array}$ & 26.52 & $\begin{array}{c}\mathbf{0 . 6 1} \\
(1-1) \\
\end{array}$ & 0.487 & $\begin{array}{l}0.63 \\
(0-1) \\
\end{array}$ & 0.482 \\
\hline DIV & $\begin{array}{c}1.18 \\
(1-5)\end{array}$ & 0.481 & $\begin{array}{c}1.16 \\
(1-5)\end{array}$ & 0.478 & $\begin{array}{c}1.19 \\
(1-5)\end{array}$ & 0.483 \\
\hline AGE & $\begin{array}{c}3.99 \\
(1-5)\end{array}$ & 0.484 & $\begin{array}{l}3.98 \\
(1-5)\end{array}$ & 1.177 & $\begin{array}{l}4.00 \\
(1-5)\end{array}$ & 1.210 \\
\hline
\end{tabular}

${ }^{1}$ Lost Cases: 4.

Table 4. Test of equality of means between family and nonfamily firms

\begin{tabular}{lc}
\hline & Difference between means \\
\hline AD_HR & 0.02 \\
\hline AD_LEG & $0.02 *$ \\
\hline SIZ & $0.17 * * *$ \\
\hline SIZ* & $0.14 * * *$ \\
\hline DEB & $2.44^{* *}$ \\
\hline EXP & $0.02 * * *$ \\
\hline DIV & 0.03 \\
\hline
\end{tabular}

Notes: $* \mathrm{p}<0.1 ; * * \mathrm{p}<0.05 ; * * * \mathrm{p}<0.01$ 
SIZ, SIZ*, the "Mann-Whitney" test was used for ordinal variables; AGE, and finally, the "Chi-Square" test was used for nominal variables AD_LEG, AD_HR, EXP.

With regards to the study of descriptive statistics (Table 4), it can be seen that the companies that make up the sample make good use of external expertise in both legal (AD_LEG) as well as staff management issues (AD_HR). In both cases, the percentage of companies that use these types of consultancy exceeds 87 percent. This percentage does not vary substantially when differentiating between family and non-family firms. In this sense, it can be seen that family businesses make greater use of advice on staff management (AD_HR) than non-family firms, the opposite occurs with legal advice (AD_LEG). However, the differences are minimal. For this reason, this study has then been completed with a test of equality of means between the two types of company, revealing that the difference between the average for family and non-family companies that use external HR advice is not significant. However, this difference is significant for the use of legal advice, albeit at a low level $(0.05<\mathrm{p}<0.1)$. We found no other studies that compared the use among family and non-family firms of advice on these issues, to enable a comparison with this data.

It may also be noted that both the size and other control variables included in the model, such as the level of debt (DEB) and exports (EXP), take on smaller values in the case of family with respect to non-family businesses. This data provides a representative sample as family businesses tend to be smaller, export less and borrow less than non-family firms (Aronoff, Astrachan 1996; Poutziouris 2001; Gallo et al. 2004; Graves, Thomas 2008). However, we wanted to give reliability to the results, performing a test of equality of means on these variables between the two types of company. The results confirm that the differences are indeed significant for these four variables: SIZ, SIZ*, DEB and EXP, in line with the papers cited. Finally, we may note that, curiously, no significant differences between the mean age (AGE) of family and non-family businesses, or the degree of diversification (DIV) between these two types of companies have been found in the results obtained, unlike other studies that have done so (Anderson, Reeb 2003; Watson 2007). Finally, Table 5 shows the results of the correlations of both variables, and the various proposed econometric models (Tables 6-9).

It can be seen that there is a significant positive correlation between the two types of advice that are studied (AD_LEG and AD_HR). Similarly, one can observe the significant negative correlation between size (SIZ, SIZ*) and family character (FAM) in line with the aforementioned studies. Another important correlation, which is positive and significant, is that which exists between size (SIZ, SIZ *) and use of expertise (and AD_AD_LEG HR). This result is also consistent with the aforementioned studies by O'Farrell et al. (1993), Bennett and Robson (1999a), Xiao and Fu (2009). It also highlights significant positive correlations between the two types of consultancy (AD AD_LEG and HR) and the variable exports (EXP) in line with the studies cited above. Companies that export have higher growth and size and therefore use more external advice (Xiao, Fu 2009). Finally, note the significant negative correlations between age of the firm (AGE) and the use of advisors (AD_AD_LEG and HR). The sign is negative due to the formulation of the variable AGE (as shown in Table 2, higher values of AGE 


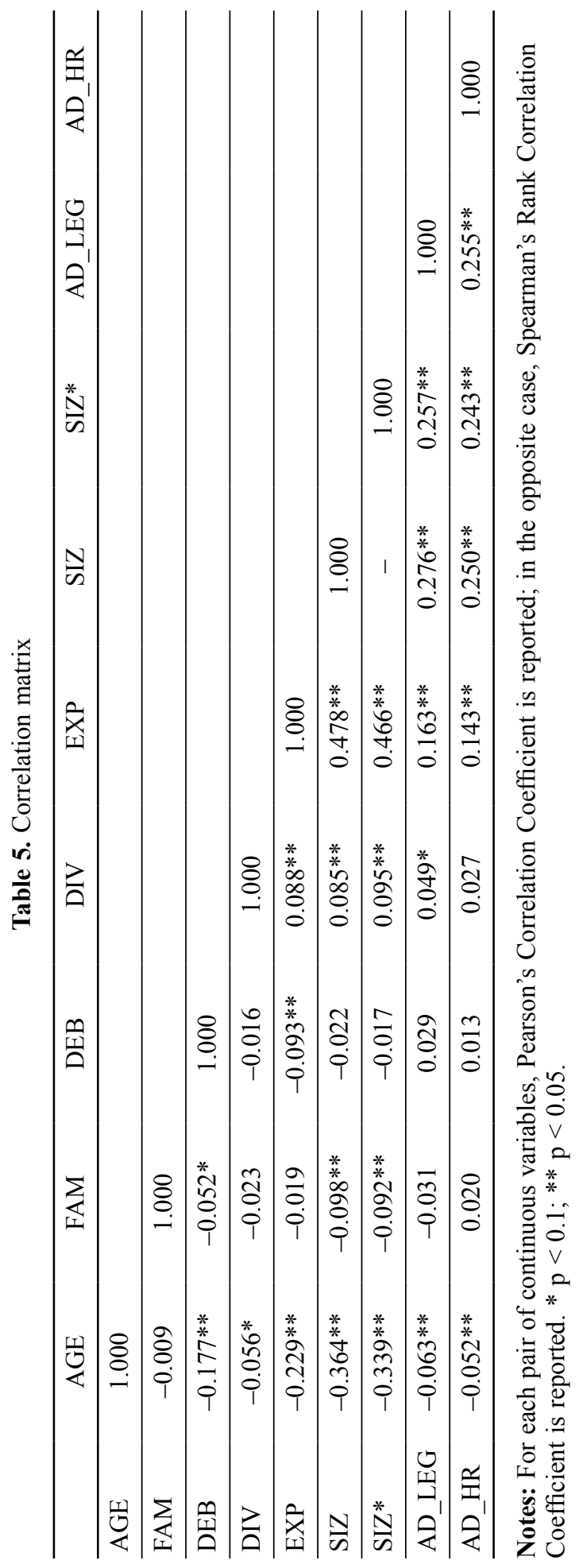


Table 6. Model 1. Dependent variable AD_LEG

\begin{tabular}{|c|c|c|c|c|}
\hline Independent variables & Coefficient $\beta$ & Standard error & Coefficient $\beta$ & Standard error \\
\hline Constant & $0.253 * * *$ & 0.072 & $0.685^{* * *}$ & 0.037 \\
\hline$[\mathrm{AGE}=1]$ & -0.005 & 0.033 & 0.005 & 0.034 \\
\hline$[\mathrm{AGE}=2]$ & -0.028 & 0.028 & -0.019 & 0.028 \\
\hline$[\mathrm{AGE}=3]$ & -0.020 & 0.019 & -0.020 & 0.020 \\
\hline$[\mathrm{AGE}=4]$ & $-0.043 * *$ & 0.019 & $-0.043 * *$ & 0.019 \\
\hline$[\mathrm{AGE}=5]$ & $0(\mathrm{a})$ & . & $0(\mathrm{a})$ & . \\
\hline$[\mathrm{FAM}=0]$ & -0.002 & 0.014 & -0.002 & 0.014 \\
\hline$[\mathrm{FAM}=1]$ & $0(\mathrm{a})$ & . & $0(\mathrm{a})$ & . \\
\hline$[\mathrm{EXP}=0]$ & $-0.030 *$ & 0.016 & $-0.042 * * *$ & 0.016 \\
\hline$[\mathrm{EXP}=1]$ & $0(a)$ & . & $0(\mathrm{a})$ & . \\
\hline DEB & 0.000487 & 0.000310 & 0.000497 & 0.000312 \\
\hline SIZ & $0.089 * * *$ & 0.010 & - & - \\
\hline SIZ* & - & - & $0.105 * * *$ & 0.013 \\
\hline DIV & 0.013 & 0.014 & 0.011 & 0.014 \\
\hline $\mathrm{R} 2$ & \multicolumn{2}{|c|}{0.075} & \multicolumn{2}{|c|}{0.066} \\
\hline
\end{tabular}

Notes: (a) Parameter is assigned a value of zero because it is redundant. ${ }^{*} \mathrm{p}<0.1$; $* * \mathrm{p}<0.05 ; * * * \mathrm{p}<0.01$.

Table 7. Model 2. Dependent variable AD_HR

\begin{tabular}{lcccc}
\hline Independent variables & Coefficient $\beta$ & Standard error & Coefficient $\beta$ & Standard error \\
\hline Constant & $0.370^{* * *}$ & 0.067 & $0.744^{* * *}$ & 0.034 \\
\hline$[\mathrm{AGE}=1]$ & -0.039 & 0.031 & -0.033 & 0.031 \\
\hline$[\mathrm{AGE}=2]$ & -0.014 & 0.027 & -0.008 & 0.027 \\
\hline$[\mathrm{AGE}=3]$ & -0.013 & 0.018 & -0.014 & 0.018 \\
\hline$[\mathrm{AGE}=4]$ & $-0.018^{*}$ & 0.018 & $-0.018^{*}$ & 0.018 \\
\hline$[\mathrm{AGE}=5]$ & $0(\mathrm{a})$ &. & $0(\mathrm{a})$ &. \\
\hline$[\mathrm{FAM}=0]$ & $-0.038^{* * *}$ & 0.013 & $-0.038^{* * *}$ & 0.013 \\
\hline$[\mathrm{FAM}=1]$ & $0(\mathrm{a})$ &. & $0(\mathrm{a})$ &. \\
\hline$[\mathrm{EXP}=0]$ & $-0.022^{*}$ & 0.015 & $-0.031^{* *}$ & 0.015 \\
\hline$[\mathrm{EXP}=1]$ & $0(\mathrm{a})$ &. & $0(\mathrm{a})$ &. \\
\hline $\mathrm{DEB}$ & 0.000309 & 0.000291 & 0.000310 & 0.000292 \\
\hline $\mathrm{SIZ}$ & $0.079^{* * *}$ & 0.009 & - & - \\
\hline $\mathrm{SIZ} *$ & - & - & $0.098^{* * *}$ & 0.012 \\
\hline $\mathrm{DIV}$ & 0.009 & 0.013 & 0.006 & 0.013 \\
\hline $\mathrm{R} 2$ & & 0.062 & & 0.057 \\
\hline
\end{tabular}

Notes: (a) Parameter is assigned a value of zero because it is redundant. $* \mathrm{p}<0.1$; $* * \mathrm{p}<0.05 ; * * * \mathrm{p}<0.01$. 
indicate that the company is younger). Therefore, coinciding with the results of Bennett and Robson (1999b), that the older the company the greater the use of external advice.

Regarding the econometric analysis proposed, Models 1 and 2 (represented in Tables 6 and 7 respectively) contain propositions $\mathrm{H}_{1}, \mathrm{H}_{2}$ and $\mathrm{H}_{4}$. These models offer a relatively low $\mathrm{R}^{2}$ ( $\mathrm{R}^{2}$ interval variables between $0.057-0.075$, depending on the proposed analyses), but these values are in line with other studies published on the same subject (e.g., Robson, Bennett 2000).

Models 1 and 2 have been built without interactions and contrast the "classic" forecast of the variables that have been included in other published empirical and theoretical papers (Bennett, Robson 1999a, 1999b, 2004; Xiao, Fu 2009; Park et al. 2010). The control variables exports (EXP) and age (AGE) take on significant values and maintain the expected sign according to the results of other studies cited. In Model 1, for the case of exports, the negative value is taken as equal to zero $\left(\beta_{\mathrm{EXP}=0}=-0,030 * /-0,042 * * *\right)$, and the ordinal variable AGE is significant and negative when it takes values greater than or equal to four, which represents younger firms $\left(\beta_{\mathrm{AGE}=4}=-0,043 * * /-0,043 * *\right)$. Furthermore, these variables keep similar values in both models (for Model 2: $\beta_{\mathrm{EXP}=0}=$ $-0,021 * /-0,031 * *$ y $\left.\beta_{\mathrm{AGE}=4}=-0,018 * * /-0,018 * *\right)$. These results are interpreted as follows: for the older and more export oriented companies we can expect greater use of advice (Bennett, Robson 2004; Xiao, Fu 2009). Xiao and Fu (2009) point out that this is because companies that export more and are in the market longer are usually larger. The positive sign is also seen in the diversification variables (DIV) and leverage (DEB) (Anderson, Reeb 2003; Watson 2007; Aronoff, Astrachan 1996) although these are not significant.

Regarding the independent variables, it can be seen that the results that relate the use of advisory services to firm size, both in Model 1 and Model 2, do not change, both being positive and very significant (Model $1: \beta_{\mathrm{SIZ}}=0,089 * * *$ and $\beta_{\mathrm{SIZ}}=0.105^{* * *}$; Model 2: $\beta_{\mathrm{SIZ}}=0,079 * * *$ and $\left.\beta_{\mathrm{SIZ}}=0.098^{* * *}\right)$. The largest companies are the ones that most use legal advice and HR (O'Farrell et al. 1993; Bennett, Robson 1999a; Xiao, Fu 2009). Although, as stated by Robson and Bennett (2000), while not all types of advice respond similarly to the same business circumstances, for these two types of advice in particular this positive relationship is fulfilled. Although, as already mentioned, the use of general advice and its relationship to size has been studied previously in the literature and found to be positive, this can also be accepted for the specific case of legal advice and HR. Thus, as expected, we can accept $\mathrm{H}_{1}$.

With regard to the results of the variable representing the family nature of the business (FAM), this is different depending on the kind of advice that is analyzed. To explain the use of external legal advice (Model 1) FAM is not significant and therefore does not support $\mathrm{H}_{4}$. These results are in line with the work of Morris et al. (1996), Astrachan et al. (2003), Matser and Lievens (2011) in which it is stated that the family business tends not to use such advice.

The same is not true in Model 2, which explains the use of external expertise in HR, taking on significant negative values for values of $\mathrm{FAM}=0\left(\beta_{\mathrm{FAM}}=0=-0,038 * * * /-0,038 * * *\right)$, 
thus supporting $\mathrm{H}_{2}$. In this case, the negative sign of beta is, as indicated, for values of $\mathrm{FAM}=0$. This means that the family nature of the business has a significant positive influence on the use of external advice for the recruitment and management of staff. After reviewing the literature concerning this issue, we conclude that family businesses tend to shun formal mechanisms for HRM. However, these studies use samples which only includes SMEs (Reid, Adams 2001; De Kok et al. 2006; Matser, Lievens 2011) while in the present study the sample includes companies of all sizes with the average size of the family business being relatively high as shown in the descriptive results (Table 4).

The second analysis contains the propositions $\mathrm{H}_{3}$ and $\mathrm{H}_{5}$, and the variables as interactions. Tables 8 and 9 show a brief summary of Models 3 and 4 regarding this second analysis. By including the interactions, we are not contrasting the "individual" influence of the variables that interest us (specifically SIZ, SIZ* and FAM), but their combined effects. However, the interactions formed by the variable FAM with the two variables that measure firm size (SIZ and SIZ*) are not significant. This is interpreted as follows: although Model 2 contrasts that the family nature and size significantly influence the

Table 8. Model 3. Dependent variable AD_LEG

\begin{tabular}{lcccc}
\hline Independent variables & Coefficient $\beta$ & Standard error & Coefficient $\beta$ & Standard error \\
\hline Constant & $0.170^{* * *}$ & 0.109 & $0.685^{* * *}$ & 0.046 \\
\hline$[\mathrm{AGE}=1]$ & -0.005 & 0.033 & 0.005 & 0.034 \\
\hline$[\mathrm{AGE}=2]$ & -0.027 & 0.028 & -0.019 & 0.028 \\
\hline$[\mathrm{AGE}=3]$ & -0.021 & 0.019 & -0.020 & 0.020 \\
\hline$[\mathrm{AGE}=4]$ & $-0.044^{* *}$ & 0.019 & $-0.043 * *$ & 0.019 \\
\hline$[\mathrm{AGE}=5]$ & $0(\mathrm{a})$ & $\cdot$ & $0(\mathrm{a})$ &. \\
\hline$[\mathrm{FAM}=0]$ & -0.121 & 0.121 & -0.003 & 0.045 \\
\hline$[\mathrm{FAM}=1]$ & $0(\mathrm{a})$ & $\cdot$ & $0(\mathrm{a})$ & $\cdot$ \\
\hline$[\mathrm{EXP}=0]$ & $-0.030^{*}$ & 0.016 & $-0.042^{* * *}$ & 0.016 \\
\hline$[\mathrm{EXP}=1]$ & $0(\mathrm{a})$ & $\cdot$ & $0(\mathrm{a})$ &. \\
\hline DEB & 0.000485 & 0.000310 & 0.000497 & 0.000312 \\
\hline $\mathrm{DIV}$ & 0.013 & 0.014 & 0.011 & 0.014 \\
\hline SIZ & $0.083 * * *$ & 0.011 & - & - \\
\hline SIZ* & - & - & $0.105^{* * *}$ & 0.015 \\
\hline INT_FAM*SIZ & 0.018 & 0.017 & - & - \\
\hline INT_FAM*SIZ* & - & - & 0.000 & 0.024 \\
\hline R2 & 0.075 & & 0.066 & \\
\hline
\end{tabular}

Notes: (a). Parameter is assigned a value of zero because it is redundant. ${ }^{*} \mathrm{p}<0.1$; ** $\mathrm{p}<0.05 ; * * * \mathrm{p}<0.01$. 
Table 9. Model 4. Dependent variable AD_HR

\begin{tabular}{|c|c|c|c|c|}
\hline Independent variables & Coefficient $\beta$ & Standard error & Coefficient $\beta$ & Standard error \\
\hline Constant & $0.406^{* * *}$ & 0.102 & $0.768 * * *$ & 0.043 \\
\hline$[\mathrm{AGE}=1]$ & -0.039 & 0.031 & -0.033 & 0.031 \\
\hline$[\mathrm{AGE}=2]$ & -0.014 & 0.027 & -0.009 & 0.027 \\
\hline$[\mathrm{AGE}=3]$ & -0.013 & 0.018 & -0.014 & 0.018 \\
\hline$[\mathrm{AGE}=4]$ & $-0.018^{*}$ & 0.018 & $-0.018^{*}$ & 0.018 \\
\hline$[\mathrm{AGE}=5]$ & 0 (a) & . & $0(\mathrm{a})$ & . \\
\hline$[\mathrm{FAM}=0]$ & -0.090 & 0.113 & $-0.074 *$ & 0.042 \\
\hline$[\mathrm{FAM}=1]$ & $0(a)$ & . & $0(a)$ & . \\
\hline$[\mathrm{EXP}=0]$ & $-0.022 *$ & 0.015 & $-0.031 * *$ & 0.015 \\
\hline$[\mathrm{EXP}=1]$ & $0(a)$ & . & $0(a)$ & . \\
\hline DEB & 0.000310 & 0.000291 & 0.000313 & 0.000292 \\
\hline DIV & 0.009 & 0.013 & 0.006 & 0.013 \\
\hline SIZ & $0.081 * * *$ & 0.010 & - & - \\
\hline SIZ* & - & - & $0.104 * * *$ & 0.014 \\
\hline INT_FAM*SIZ & -0.008 & 0.016 & - & - \\
\hline INT_FAM*SIZ* & - & - & -0.020 & 0.022 \\
\hline $\mathrm{R} 2$ & \multicolumn{2}{|c|}{0.062} & \multicolumn{2}{|c|}{0.057} \\
\hline
\end{tabular}

Notes: (a). Parameter is assigned a value of zero because it is redundant. ${ }^{*} \mathrm{p}<0.1$; ** $\mathrm{p}<0.05 ; * * * \mathrm{p}<0.01$

use of external advice in HR, the truth is that it cannot be deduced that there is a joint effect which implies that the size of the family business enterprise positively influences the use of external advice, that is to say that larger family businesses use this advice more than smaller ones.

In this second analysis, the coefficients of the "individual" variables (without interaction) SIZ, SIZ* FAM remain significant and maintain their sign. In any case, what is of interest is the interpretation of the interaction terms. According to the so called "principle of marginality" (Nelder 1977) when the interaction terms are significant, the values of individual variables (called "main effects") should not be tested or interpreted (Fox 2008). As the interactions in this study are not significant, the main terms for these variables reflect intrinsic properties of the data and must be taken into account.

The coefficients of the remaining individual variables without other interactions (DEB, DIV, EXP, AGE) do not substantially change and maintain their level of significance, which is a measure of robustness. Furthermore, the second analysis (Models 3 and 4) does not improve on the indicators of goodness of fit in the first analysis (Models 1 and 2) 
$\mathrm{R}^{2}$, indicating that the interactions that have been added are not relevant. Thus, the results do not support the hypothesis $\mathrm{H}_{3}$ and $\mathrm{H}_{5}$, in line with the work of Lussier et al. (2009). This paper proposed a hypothesis relating the size of the family business and the formal mechanisms employed in running it, to the use of advice, but this was also unconfirmed by the empirical analysis.

\section{Conclusions}

\section{Theoretical contributions and managerial implications}

This paper has analyzed the relationship between the family nature and size of a firm with the use of external advice on legal matters and HR. Based on the literature we concluded that, in general terms, a positive relation exits between size and the use of external advice. Nevertheless, this relation can change depending on the type of advice which is analyzed. In this paper we study the advice on legal matters and HR because they represent two major concerns for family businesses. Therefore, according to the literature, the results will vary depending on the type of advice analyzed. Specifically the results obtained confirm the first hypothesis, so we conclude that for all companies in general, the greater the size, the greater the use of external advice.

However, in relation to family nature, different results are achieved. In line with the literature (Morris et al. 1996; Astrachan et al. 2003; Matser, Lievens 2011), we have found that it does not significantly influence the use of legal advice, but we found substantial differences regarding the use of HR advice. The results show that family firms tend to use more HR advice than non-family firms. This surprising finding contradicts previous literature (Reid, Adams 2001; De Kok et al. 2006; Matser, Lievens 2011), the discrepancy may be due to two fundamental facts. The published works were performed with samples of SMEs, while in the present study we have used a sample that also includes large family businesses. The second issue that may explain this finding is the average age of the family firms that make up the sample, namely established companies, as the descriptive results show.

These two characteristic aspects of the sample: greater company size and greater experience in the market could explain the use of professionalized procedures for HRM, while smaller companies use more informal and flexible systems. In this sense, we suspect that when family firms grow they behave as non-family firms regarding the use of HR advice. Moreover, the second analysis develop to prove this idea, aimed to provide further information on the relationship between the size of the family firm and the use of external advice; however, the results were not significant, so it can't be concluded that there is a positive relationship between firm size and use of external advice. Therefore, it cannot be confirmed that larger family businesses behave like non-family firms, when referring to the use of legal and HR advice.

Since it has not been shown that the use of HR advice in family firms depends on the size of the company $\left(\mathrm{H}_{3}\right)$, it is necessary to put forward other reasons that may explain our findings. In view of the results relating to the variable AGE, one can intuit that the age of the company is a factor to be considered in the family business, equally as 
important as the size, as published studies indicate (Sondfield, Lussier 2008). Indeed, younger firms tend to use significantly less HR advice than older ones. This could be due to nepotism, something which is a far more common circumstance in family firms than in non-family ones, and, in particular, in young family businesses. However, with generational change, especially from the second to the third and subsequently, the need arises to involve people from outside the family, and becomes more usual to request external advice. Thus, we can conclude that the greater use of HR advice in family firms can be better explained by the age and the generational change of the firm, rather than by the size of the company.

In general terms, as mentioned, nepotism tends to occur more frequently in the first generations. However as time passes, if this attitude continues, it can threaten the future of the business. Such continuity depends, greatly, on how professionally it is administered. This includes among other factors, the use of external advisors and professional services, in order to achieve the proper management of its HR, since human capital is the most important asset for all companies, as well as a key factor in business development and success.

Regarding legal advice, the results of this research show, in line with other cited studies, that the family nature does not have a significant influence on the use of such advice. Hence, we cannot conclude that the larger the size of family firms, the more they use legal external advice. Nevertheless, problems associated with succession and other conflicts affecting family relationships constitute one of the main concerns of family firms and proper management of potential conflicts in these areas is key to continuity. Indeed, these are issues that significantly affect these businesses, so the use external advice in this area is recommended.

Finally, we may conclude that for family businesses external advice is necessary, not only in HR (which they already make use of as this paper demonstrates), but also concerning legal matters, to guarantee the continuity of the business. It is important to note that the advisors must take into account the peculiarities and emotional aspects of the family businesses they advise.

\section{Limitations and recommendations for future research}

There are four main limitations in this paper of which the first is the national character of the sample and the second the temporary horizon limited to one year of study (a cross sectional research). However, the relationship between use of advice and firm size is not expected to change substantially over time, in line with other previously published studies (Bennett, Robson 1999a; Sonfield, Lussier 2008; Xiao, Fu 2009). Thirdly, being a study of a particular sector: the industrial sector. In this sense, it is important to note that, a priori, the influence of the sector is less important, since many needs are common to all sectors. Finally, a reverse causality effect between the analyzed variables: size and external advising could exist. Nevertheless, given the structure of the managed data it is not possible to find suitable instrumental variables in order to develop Hausman's Test and prove the existence of such causality. However, the adjustment of the model to the 
existing literature, in which the use of external advise is explained with regard to the size of the company, could justify the causal relationship between the proposed variables in the analysis, since it has been decided to follow this research line (O'Farrell et al. 1993; Robson, Bennett 1999a, 1999b; Sonfield, Lussier 2008; Xiao, Fu 2009).

With regard to future research, it would be interesting to carry out this study with a sample of medium-sized companies (50 to 250 employees), and analyzing how the age variable affects the company's use of external advice. Another aspect that should also be studied is the influence of the lack of professionalism of the family business and how this issue encourages the use of external advice. A more detailed study could also be carried out, on the use of financial, fiscal or economic advice, observing the kind of relationships they have with the size, age, level of professionalism and family character of the firm. An extension of this paper is also intended using panel data, carrying out a more in-depth analysis of the size of the family business and the use it makes of advice, since the results obtained have not allowed for the elucidation of the proposed hypotheses 4 and 5. Finally, it would be interesting to repeat this analysis with data from other countries with larger business enterprise frameworks.

\section{References}

I Foundation. 2011. Encuesta de Estrategias Empresariales [online], [cited 8 November 2011]. Available from Internet: http://www.funep.es/esee/sp/sinfo_que_es.asp

Anderson, R. C; Reeb, D. M. 2003. Founding-family ownership and firm performance: evidence from S\&P 500, The Journal of Finance 63(3): 1301-1326.

http://dx.doi.org/10.1111/1540-6261.00567

Alewell, D.; Hauff, S.; Weiland, K.; Thommes, K. 2011. HRM and the use of personnel services: an empirical analysis of German firms, International Journal of Manpower 32(4): 394-409. http://dx.doi.org/10.1108/01437721111148522

Aronoff, C. 1998. Megatrends in family business, Family Business Review 11(3): 181-192.

Aronoff, C.; Astrachan, J. 1996. Reducing the risks of family-business growth, Nation's Business 84(3): 52-53. http://dx.doi.org/10.1111/j.1741-6248.1998.00181.x

Arteaga, J.; Medina, D. 2006. La importancia del tamaño en la actividad exportadora, Boletín Económico de ICE 2883: 41-54.

Astrachan, J. H.; Kolenko, T. A. 1994. A neglected factor explaining family business success human resource practices, Family Business Review 7: 251-262.

http://dx.doi.org/10.1111/j.1741-6248.1994.00251.x

Astrachan, J. H.; Zahra, S. A.; Sharma, P. 2003. Family-sponsored ventures. Kansas City: MO: Kauffman Foundation.

Bagley, C. 2008. Winning legally: the value of legal astuteness, Academy of Management Review 33(2): 378-390. http://dx.doi.org/10.5465/AMR.2008.31193254

Barber, A.; Wesson, M.; Roberson, Q.; Taylor, S. 1999. A tale of two job markets: organisational size and its side effects on hiring practices and job search behavior, Personnel Psychology 52(4): 841-867. http://dx.doi.org/10.1111/j.1744-6570.1999.tb00182.x

Barney, J. B. 1991. Firm resources and sustained competitive advantage, Journal of Management 17(1): 99-120. http://dx.doi.org/10.1177/014920639101700108 
Barrett, R.; Mayson, S. 2007. Human resource management in growing small firms, Journal of Small Business and Enterprise Development 14(2): 307-320.

http://dx.doi.org/10.1108/14626000710746727

Barron, J. M.; Black, D. A.; Loewenstein, M. A. 1987. Employer size: the implications for search, training, capital investment, starting wages, and wage growth, Journal of Labor Economics 5(1): 76-89. http://dx.doi.org/10.1086/298138

Beckhard, R.; Dyer, W. 1983. Managing continuity in family-owned business, Organizational Dynamics 12(1): 5-12. http://dx.doi.org/10.1016/0090-2616(83)90022-0

Benavides, C.; Guzmán, V.; Quintana, C. 2011. Evolución de la literatura sobre empresa familiar como disciplina científica, Cuadernos de Economía y Dirección de la Empresa 14: 78-90.

http://dx.doi.org/10.1016/j.cede.2011.02.004

Bennett, R.; Robson, P. 1999a. The use of external business advice by SMEs in Britain, Entrepreneurship and Regional Development 11: 155-180. http://dx.doi.org/10.1080/089856299283245

Bennett, R; Robson, P. 1999b. Intensity of interaction in supply of business advice and client impact: a comparison of consultancy, business associations and government support initiatives for SMEs', British Journal of Management 10: 351-369. http://dx.doi.org/10.1111/1467-8551.00144

Bennett, R.; Robson, P. 2003. Changing use of business advice and government supports by SMEs in the 1990s, Regional Studies 37(8): 795-811. http://dx.doi.org/10.1080/0034340032000128721

Bennett, R.; Robson, P. 2004. The role of boards of directors in small and medium-sized firms, Journal of Small Business and Enterprise Development 11(1): 95-113.

http://dx.doi.org/10.1108/14626000410519137

Bennett, R.; Robson, P. 2005. The advisor-SME client relationship: impact, satisfaction and commitment, Small Business Economics 25: 255-271. http://dx.doi.org/10.1007/s11187-003-6459-3

Bennett, R.; Smith, C. 2002. The influence of location and distance on the supply of business advice, Environment and Planning A 34: 251-270. http://dx.doi.org/10.1068/a34136

Birley, S. 1986. Succession in the family firm: the inheritor's view, Journal of Small Business Management 24(3): 36-43.

Bonaccorsi, A. 1992. On the relationship between firm size and export intensity, Journal of International Business Studies 23(4): 605-635. http://dx.doi.org/10.1057/palgrave.jibs.8490280

Boter, H.; Lundström, A. 2001. Support services to SMEs. Analysis of support actors and company characteristics, in Conference Proceedings, vol. 2, 22-23 November, 2001, Turku-Finland.

Cabrera-Suárez, K; De Saá-Pérez, P.; García-Almeida, D. 2001. The succession process from a resource-and knowledge-based view of the family firm, Family Business Review 14(1): 37-48. http://dx.doi.org/10.1111/j.1741-6248.2001.00037.x

Calof, J. L. 1994. The impact of size on internationalization, Journal of Small Business Management 25(2): 60-69.

Chaganti, R.; Chaganti, R. 1983. A profile of profitable and not-so-profitable small businesses, Journal of Small Business Management 21(3): 43-51.

Chua, J.; Chrisman, J.; Sharma, P. 2003. Succession and nonsuccession concerns of family firms and agency relationship with nonfamily managers, Family Business Review 16(2): 89-107.

http://dx.doi.org/10.1111/j.1741-6248.2003.00089.x

Claver, E.; Quer, D. 2007. Determinants of Spanish foreign direct investment in Morocco, Emerging Markets Finance and Trade 43(2): 19-32. http://dx.doi.org/10.2753/REE1540-496X430202

Claver, E.; Rienda, L.; Quer, R. 2008. Incide el carácter familiar en el compromiso internacional de las empresas españolas, Investigaciones Europeas de Dirección y Economía de la Empresa 13(3): $13-32$. 
Daily, C. M.; Dollinger, M. J. 1992. An empirical examination of ownership structure in family and professionally managed firms, Family Business Review 5(2): 117-136.

http://dx.doi.org/10.1111/j.1741-6248.1992.00117.x

Danes, S. M.; Stafford, K.; Haynes, G.; Amarapurkar, S. 2009. Family capital of family firms: bridging human, social, and financial capital, Family Business Review 22: 199-216.

http://dx.doi.org/10.1177/0894486509333424

Dawson, A. 2012. Human capital in family businesses: focusing on the individual level, Journal of Family Business Strategy 3: 3-11. http://dx.doi.org/10.1016/j.jfbs.2011.12.001

De Kok, J. M. P.; Uhlaner, L. M.; Thurik, A. R. 2006. Professional HRM practices in family owned-managed enterprises, Journal of Small Business Management 44(3): 441-460.

http://dx.doi.org/10.1111/j.1540-627X.2006.00181.x

Deshpande, S.; Golhar, D. 1994. HRM practices in large and small manufacturing firms: a comparative study, Journal of Small Business Management 32(2): 49-56.

Dyer, W. G., Jr. 1986. Cultural change in family firms. San Francisco, CA: Jossey-Bass.

Dyer, W. G., Jr. 1988. Culture and continuity in family firms, Family Business Review 1: 37-50. http://dx.doi.org/10.1111/j.1741-6248.1988.00037.x

Dyer, L. M.; Ross, C. A. 2008. Seeking advice in a dynamic and complex business environment: impact on the success of small firms, Journal of Developmental Entrepreneurship 13(2): 133-149.

Fernández, Z.; Nieto, M. J. 2005. Internationalization strategy of small and medium-sized family businesses: some influential factors, Family Business Review 18(1): 77-89.

http://dx.doi.org/10.1111/j.1741-6248.2005.00031.x

Fox, J. 2008. Applied regression analysis and generalized linear models. $2^{\text {nd }}$ ed. Thousand Oaks: Sage.

Gallo, M. A.; García Pont, C. 1996. Important factors in family business internationalization, Family Business Review 9(1): 45-59. http://dx.doi.org/10.1111/j.1741-6248.1996.00045.x

Gallo, M.; Corbetta, G.; Dyer, G.; Montmerlo, D.; Tomaseli, S.; Cappuyns, K. 2001. Success as a function of love, trust and freedom in family businesses, in Family Business Chair, Monographic, 4. IESE, Barcelona.

Gallo, M. A.; Tàpies, J.; Cappuyns, K. 2004. Comparison of family and nonfamily business: financiallogic and personal preferences, Family Business Review 17(4): 303-318.

http://dx.doi.org/10.1111/j.1741-6248.2004.00020.x

Gallo, M. A.; Klein, S.; Tomaselli, S.; Montermerlo, D.; Cappuyns, K. 2009. La empresa familiar multigeneracional. Navarra: EUNSA.

García Quevedo, J.; Mas, F. 2007. Tamaño empresarial y uso de servicios intensivos en conocimiento, X Encuentro de Economía Aplicada, junio, Logroño, Spain.

Gaskill, L.; Van Auken, H.; Manning, R. 1993. A factor analytic study of the perceived causes of small business failure, Journal of Small Business Management 31(4): 18-31.

Giles, H.; Beasley, F.; White, R. 2009. Selecting a legal structure: revisiting the strategic issues and views of small and micro business owners, Journal of Small Business Strategy 20(1): 81-101.

Graves, C.; Thomas, J. 2004. Internationalisation of the family business: a longitudinal perspective, International Journal of Globalisation and Small Business 1(1): 7-27.

http://dx.doi.org/10.1504/IJGSB.2004.005615

Graves, C.; Thomas, J. 2008. Determinants of the internationalization pathways of family firms: an examination on family business, Family Business Review 21(2): 151-167.

http://dx.doi.org/10.1111/j.1741-6248.2008.00119.x 
Greene, W. H. 2000. Econometric analysis. $4^{\text {th }}$ ed. Upper Saddle River, New York: Prentice Hall. Gulbrandsen, T. 2005. Flexibility in Norwegian family-owned enterprises, Family Business Review 18(1): 57-76. http://dx.doi.org/10.1111/j.1741-6248.2005.00030.x

Habbershon, T. G.; Williams, M. L. 2000. A model for understanding the competitiveness of family-controlled companies, in P. Poutziouris (Ed.). Tradition or entrepreneurship in the new economy. Manchester Business School, Manchester. 94-115.

Handler, W. C. 1989. Methodogical issues and considerations in studying family business, Family Business Review 2(3): 257-276. http://dx.doi.org/10.1111/j.1741-6248.1989.00257.x

Handler, W. C. 1994. Succession in family business a review of the research, Family Business Review 7(2): 133-157. http://dx.doi.org/10.1111/j.1741-6248.1989.00257.x

Hornsby, J. S.; Kuratko, D. K. 1990. Human resource management in small business: critical issues for the 1990s, Journal of Small Business Management 28(3): 9-18.

Hutchinson, J.; Konings, J.; Walsh, P. P. 2010. The firm size distribution and inter-industry diversification, Review of Industrial Organization 37: 65-82.

http://dx.doi.org/10.1007/s11151-010-9260-x

Insik, J. 2003. A cross-national study of the relationship between international diversification and new product performance, International Marketing Review 20(4): 353-376.

http://dx.doi.org/10.1108/02651330310485144.

Johnson, S.; Webber, D. J.; Thomas, W. 2004. Factors influencing the use of external business advice, in T. Cooney, P. Malinen (Eds.). New perspectives on firm growth. Council for Small Business and Entrepreneurship, Turku.

Johnson, S.; Webber, D. J.; Thomas, W. 2007. Which SMEs use external business advice? A multivariate subregional study, Environment and Planning A 39: 1981-1997.

http://dx.doi.org/10.1068/a38327

Jorissen, A.; Laveren, E.; Martens, R.; Reheul, A.-M. 2005. Real versus sample-based differences in comparative family business research, Family Business Review 18(3): 229-246.

http://dx.doi.org/10.1111/j.1741-6248.2005.00044.x

Karlsson, A. 2001. En famille: invisible managers in owner families, in Academic Research Forum Proceedings, FBN 12 ${ }^{\text {th }}$ Annual World Conference Rome, 2001, University School of Management, Bocconi.

Kent, P. 1994. Management advising services and the financial performance of clients, International Small Business Journal 12(4): 45-45. http://dx.doi.org/10.1177/0266242694124003

Klyver, K. 2008. The shifting consultant involvement, Journal of Small Business and Enterprise Development 15(1): 178-193. http://dx.doi.org/10.1108/14626000810850919

Kotey, B.; Folker, C. 2007. Employee training in SMEs: effect of size and firm type-family and nonfamily, Journal of Small Business Management 45(2): 214-238.

Lansberg, I. 1983. Managing human resources in family firms: the problem of institutional overlap, Organizational Dynamics 12(1): 39-46. http://dx.doi.org/10.1016/0090-2616(83)90025-6

Lansberg, I. 1988. The succession conspiracy, Family Business Review 1(2): 119-143.

http://dx.doi.org/10.1111/j.1741-6248.1988.00119.x

Lansberg, I. 1999. Succeeding generations: realizing the dream of families in business. Boston, MA: Harvard Business School Press.

Lansberg, I.; Astrachan, P. 1994. Influence of family relationships on succession planning and training: the importance of mediating factors, Family Business Review 7(1): 39-59.

http://dx.doi.org/10.1111/j.1741-6248.1994.00039.x

Larimo, J. 1997. Ownership structures of finnish firms' foreign subsidiaries in EU countries, in I. Björkman, M. Forsgren (Eds.). The nature of the international firm, Nordic contributions to international business research. Copenhagen: Copenhagen Business School Press, 281-308. 
Le Breton-Miller, I.; Miller, D.; Steier, L. 2004. Toward an integrative model of effective FOB succession, Entrepreneurship Theory and Practice 28(4): 305-328.

http://dx.doi.org/10.1111/j.1540-6520.2004.00047.x

Lee, J. 2006. Family firms performance: further evidence, Family Business Review 19(2): 103114. http://dx.doi.org/10.1111/j.1741-6248.2006.00060.x

Leighton, J.; Schaper, M. 2003. Which advisers do micro-firms use? Some Australian evidence, Journal of Small Business and Enterprise Development 10(2): 136-144.

http://dx.doi.org/10.1108/14626000310473166

Lin, X.; Germain, R. 2003. Organizational structure, context, customer orientation, and performance: lessons from Chinese state-owned enterprises, Strategic Management Journal 24: 1131-1151. http://dx.doi.org/10.1002/smj.348

Longenecker, J. G.; Petty, C. W.; Moore, J. W.; Palich, L. E. 2006. Small business management, an entrepreneurial emphasis. London: Thomson South Western.

López, A.; Rosell, J. 2007. Subcontratación y Teoría de los Costes de Transacción: valoraciones de la incertidumbre para las empresas manufactureras españolas, Revista Europea de Dirección y Economía de la Empresa 16(3): 9-22.

Lucio, J. J.; Mónguez, R.; Álvarez, D. 2007. El tamaño de la empresa exportadora e importadora española, Boletín Económico de ICE 2908: 13-30.

Lussier, R.; Sonfield, M.; Barbato, R. 2009. Family member and non family member managers in family firms: adding a seventh country to the international database Kosovo, Journal of Small Business Strategy 20(2): 97-114.

Matser, I.; Lievens, J. 2011. The succession scorecard, a tool to assist family business's transgenerational continuity, International Journal of Entrepreneurial Venture 3(2): 101-124.

http://dx.doi.org/10.1504/IJEV.2011.039336

McCullagh, P.; Nelder, J. 1989. Generalized linear models, Chapter 1. London: Chapman and Hall. http://dx.doi.org/10.1007/978-1-4899-3242-6

Merino, F.; Rodríguez Rodríguez, D. 2007. Business services outsourcing by manufacturing firms, Industrial and Corporate Change 16(6): 1147-1173. http://dx.doi.org/10.1093/icc/dtm034

Morris, M.; Williams, R.; Nel, D. 1996. Factors influencing family business succession, International Journal of Entrepreneurial Behaviour \& Research 2(3): 68-81.

http://dx.doi.org/10.1108/13552559610153261

Nelder, J. A. 1977. A reformulation of linear models, Journal of the Royal Statistical Society Series A, 140(1): 49-77. http://dx.doi.org/10.2307/2344517

Nelder, J. A.; Wedderburn, R. W. M. 1972. Generalized linear models, Journal of the Royal Statistic Society 137(A): 370-384.

Nueno, P. 2011. Iniciativa emprendedora y empresa familiar: emprendiendo a través de las generaciones, Universia Business Review 32: 96-101.

O'Farrell, P. N.; Hichens, D. M.; Moffat, L. A. R. 1993. Manufacturing demand for a business services in a core and peripherical region: does flexible production imply vertical disintegration of business services, Regional Studies 27(5): 519-533.

http://dx.doi.org/10.1080/00343409312331347645

Park, Y.; Shin, J.; Kim, T. 2010. Firm size, age, industrial networking, and growth: a case of the Korean manufacturing industry, Small Business Economics 35: 153-168.

http://dx.doi.org/10.1007/s11187-009-9177-7

Parker, J. E. S. 1978. The economics of innovation. The national and multinational enterprise in technological change. $2^{\text {nd }}$ ed. Longman Group Limited.

Peteraf, M. A. 1993. The cornerstones of competitive advantage: a resource-based view, Strategic Management Journal 14: 179-191. http://dx.doi.org/10.1002/smj.4250140303 
Poutziouris, P. 2001. The views of family companies on venture capital: empirical evidence from the UK small to medium-size enterprising economy, Family Business Review 14(3): 277-291. http://dx.doi.org/10.1111/j.1741-6248.2001.00277.x

Poza, E. 2004. Family business. Mason, Ohio: Thomson Southwestern.

Priede, T.; López-Cózar, C. 2009. Importancia de la unidad y el compromiso del equipo en la administración de la empresa familiar, Gaudeamus 1: 171-189.

Prodan, A.; Slavec, I. 2012. The influence of entrepreneur's characteristics on small manufacturing firm debt financing, Journal for East European Management Studies 17(1): 104-130. http://dx.doi.org/10.1108/03090590110401782

Reid, R. S.; Adams, J. S. 2001. Human resource management - a survey of practices within family and non-family firms, Journal of European Industrial Training 25(6/7): 310-320.

http://dx.doi.org/10.1108/03090590110401782

Reynolds, P. D. 1987. New firms societal contribution versus survival potential, Journal of Business Venturing 2: 231-246. http://dx.doi.org/10.1016/0883-9026(87)90011-5

Robson, P.; Bennett, R. 2000. SME growth: the relationship with business advice and external collaboration, Small Business Economics 15(3): 193-208. http://dx.doi.org/10.1023/A:1008129012953

Robson, P.; Bennett, R. 2009. Paying fees for government business advice: an assessment of Business Link experience, Applied Economics 42(01): 37-48.

http://dx.doi.org/10.1080/00036840701579184

Rollock, A. 1998. Professional responsibility and organization of the family business: the lawyer as intermediary, Indiana Law Journal 73(2): 565-587.

Romano, C. A.; Tanewski, G. A.; Smyrnios, K. X. 2001. Capital structure decision making: a model for family business, Journal of Business Venturing 16(3): 285-310.

http://dx.doi.org/10.1016/S0883-9026(99)00053-1

Saari, L. M.; Johnson, T. R.; McLaughlin, S. D.; Zimmerle, D. M. 1988. A survey of management training and education practices in US companies, Personnel Psychology 41: 731-43.

http://dx.doi.org/10.1111/j.1744-6570.1988.tb00650.x

Said, K. E.; Hughey, K. J. 1977. Managerial problems of the small firm, Journal of Small Business Management 15(1): 37-42.

Sharma, P.; Chua, J. H.; Chrisman, J. J. 2000. Perceptions about the extent of succession planning in Canadian family firms, Canadian Journal of Administrative Science 17(3): 233-244.

http://dx.doi.org/10.1111/j.1936-4490.2000.tb00223.x

Sharma, P.; Chrisman, J. J.; Chua, J. H. 2003. Succession planning as planned behavior: some empirical results, Family Business Review16(1): 1-15.

http://dx.doi.org/10.1111/j.1741-6248.2003.00001.x

Smallbone, D.; North, D.; Leigh, R. 1993. The use of external assistance by mature SMEs in the UK: some policy implications, Entrepreneurship and Regional Development 5: 279-295.

http://dx.doi.org/10.1080/08985629300000017

Smallbone, D.; Bladock, R.; North, D. 2003. Policy support for small firms in rural areas: the English experience, Environment and planning, C: Government \& Policy 21(6): 825-841.

http://dx.doi.org/10.1068/c0316

Sonfield, M.; Lussier, R. 2008. The influence of family business size on management activities, styles and characteristics, New England Journal of Entrepreneurship 11(2): 47-56.

Stern, I.; Henderson, A. D. 2004. Within-business diversification in technology-intensive industries, Strategic Management Journal 25(5): 487-455. http://dx.doi.org/10.1002/smj.400

Taylor, S. 1994. The relationship between sources of new employees and attitudes toward the job, The Journal of Social Psychology 134(1): 99-111. 
http://dx.doi.org/10.1080/00224545.1994.9710888

Torres-Fuchslocher, C.; Fuente Mella, H. 2011. Determinantes de la innovación en empresas de turismo en Pucón - Chile, Panorama Socioeconómico 29(42): 24-42.

Trau, F. 1996. Why do firms grow?, Working Paper No. 26. ESRC Centre for Business Research, University of Cambridge.

Tucker, J. 2011. Keeping the business in the family and the family in business: what is the legacy?, Journal of Family Business Management 1(1): 65-73.

http://dx.doi.org/10.1108/20436231111122290

Ward, J. 2011. How family values and vision drive business strategy and continuity, Universia Business Review 32: 26-38.

Watson, J. 2007. Modeling the relationship between networking and firm performance, Journal of Business Venturing 22: 852-874. http://dx.doi.org/10.1016/j.jbusvent.2006.08.001

Webber, D.; Johnson, S.; Fargher, S. 2010. Sector variations in SMEs' use of external business advice, Local Economy 25(4): 339-355. http://dx.doi.org/10.1080/02690942.2010.498959

Yasuda, T. 2005. Firm growth, size, age and behavior in Japanese manufacturing, Journal Small Business Economics 24(1): 1-15. http://dx.doi.org/10.1007/s11187-005-7568-y

Xiao, J.; Fu, H. 2009. An empirical study of usage of external business services by Chinese SMEs, Journal of Enterprise Information 22(4): 423-440.

Sonia BENITO-HERNÁNDEZ, PhD in Financial Economy (Universidad Complutense de Madrid). After a stage of professional development in the financial sector, she focused her energies on academic activities. She is now a Professor in business organization at Universidad Politécnica de Madrid. She also belongs to the Research School of Cooperative Studies of the Universidad Complutense de Madrid. Her research focuses on SMEs and family businesses with books and papers published in scientific journals.

Cristina LÓPEZ-CÓZAR-NAVARRO, PhD in Business and Economics (Universidad Europea de Madrid), is a Professor of Business Organization at the Universidad Politécnica de Madrid. Her more recent research interest includes SMEs and family businesses with books and papers published in scientific journals as well as international congresses.

Tiziana PRIEDE-BERGAMINI, PhD in Financial Economy (Universidad Complutense de Madrid), is a Professor at Universidad Europea de Madrid. Her major areas of research and teaching include business management, entrepreneurship, SMEs and family business. She is the author of several books and articles in scientific journals related to these topics. 